\title{
I.P. Костюк
}

\section{ВПЛИВ ПАТОЛОГІЇ ПЕРІОДОНТА НА ЗАГАЛЬНИЙ СТАН ОРГАНІЗМУ. СУЧАСНІ МЕТОДИ МЕДИКАМЕНТОЗНОГО ЛІКУВАННЯ ПЕРІОДОНТИТУ ПОСТІЙНИХ ЗУБІВ: ПЕРЕВАГИ ТА НЕДОЛІКИ (ОГЛЯД ЛІТЕРАТУРИ)}

ДВНЗ «Івано-Франківський національний медичний університет»

Резюме. У статті проаналізовано дані літератури щодо проблеми впливу хронічної одонтогенної вогнищевої інфекції, якою є періодонтит, на загальний стан організму людини. Проведено аналіз існуючих методів місцевого та загального лікування патології періодонта, висвітлено їх переваги та недоліки. Обгрунтовано необ-

Патологія періодонта завдає хворим відчутних страждань (особливо при загостренні процесу), є найбільш частою причиною втрати зубів і може бути джерелом хронічної інтоксикації організму [6]. Окрім того, тривале запалення верхівкового перицементу є серйозною загрозою розвитку хроніосептичних станів [18]. Тому хронічне запалення періодонта відноситься до стоматогенних (одонтогенних) вогнищ інфекції. Таким же вогнищем інфекції, окрім верхівкових періодонтитів, $є$ кісти, хронічні форми запалення пульпи, а також хронічний запальний та запально-дистрофічний процес у тканинах пародонта [6, 44].

Наслідками періодонтитів можуть бути такі тяжкі ускладнення місцевого характеру, як запальні процеси щелепно-лицевої ділянки (періостит, абсцес, остеомієліт, флегмона). За даними М.М. Пожарицкой и соавт. [32], періодонтит у 98-99 \% спостережень $є$ причиною флегмон щелепно-лицевої ділянки, що досить небезпечно для здоров'я і життя хворого.

Уплив хронічного апікального періодонтиту на організм через сенсибілізацію, зниження імунної реактивності та наявність ознак автоінтоксикації очевидний $[5,28]$. Тривале існування локального вогнища інфекції супроводжується підвищенням сенсибілізації організму до дії того чи іншого подразника, що має несприятливий вплив на імунологічний статус $[18,28]$.

Через імунокомплексний i цитотоксичний механізм перехресного реагування можливе ураження тих внутрішніх органів, тканини яких мають антигенну схожість до тканин стрептокока (найбільш частого збудника одонтогенних інфекцій). Це може призвести до розвитку гломерулонефриту, ревматизму, пієлонефриту, міокардиту, ревматоїдного артриту, вузликового періартеріїту, системного червоного вовчака, склеродермії, дерматоміозиту, відомих як хвороби циркулюючих імунних комплексів, і низки інших системних захворювань сполучної тканини [7, 18, 23].

Клінічна оцінка інфекційно-запальних захворювань пульпи і періодонта традиційно трактується як вірогідне джерело інфекції, що може поширюватися в першу чергу на ЛОР-органи, а далі - у глибокі відділи респіраторного тракту. У (C) I.P. Костюк, 2014 хідність комплексного лікування хронічного та загостреного періодонтиту постійних зубів. Вказано на доцільність використання рослинних засобів у терапії патології періодонта.

Ключові слова: загальний стан організму, періодонтит постійних зубів, медикаментозне лікування.

разі генералізації інфекційного процесу може розвиватися одонтогенний сепсис, одонтогенний медіастеніт, внутрішньочерепні запальні процеси, бактеріальний ендокардит, септична пневмонія та інші тяжкі захворювання [7, 32, 35].

Досліджено наявність тісного взаємозв'язку між органами ротової порожнини і шлунковокишкового тракту. Оскільки рот - це початковий відділ травної системи, то зв'язок його з іншими органами травної системи безсумнівний. Отже, різні патологічні процеси в ротовій порожнині можуть спричиняти або погіршувати перебіг патологічних процесів в органах шлунковокишкового тракту. Так доведено, що активність холінестераз крові у хворих, які страждають різними формами хронічного верхівкового періодонтиту, достовірно відрізняється від такої у практично здорових людей, які не мають одонтогенних чи інших вогнищ інфекції [23].

При періодонтиті встановлено порушення кісткового метаболізму, який вивчався в експериментальних дослідженнях за активністю маркерів кісткової тканини та вмістом кальцію і фосфору. Встановлені виражені метаболічні зсуви та порушення мінерального обміну в ділянці кісткової тканини, яка прилягає до кореня ураженого зуба. За таких умов у ній виникає локальна активація остеокластів, на що вказує достовірне підвищення активності кислої і лужної фосфатаз, причому такі зміни з боку лужної фосфатази є компенсаторною реакцією кісткової тканини. Водночас відбувається зменшення рівня кальцію та співвідношення кальцій/фосфор. У разі періодонтиту в експерименті виявлено також порушення в системі перекисне окиснення ліпідів-антиоксидантний захист: зростання активності процесів перекисного окиснення ліпідів та зниження функціональної активності антиоксидантної системи [10].

Кафедра внутрішніх захворювань стоматологічного факультету Санкт-Петербурзького державного медичного університету ім. акад. І.П. Павлова має багаторічний досвід вивчення взаємозв'язку хронічних вогнищ інфекції в ротовій порожнині із захворюваннями внутрішніх органів. У своїх дослідженнях И.А. Горбачева і А.И. Кирсанов [8] показують роль хронічних вогнищ одон- 
тогенної інфекції в розвитку загальносоматичних захворювань, приводять клінічні докази генералізації інфекційного процесу в організмі, ініціювання ним формування патологічних проявів імунодефіцитних станів, розвитку багатофакторних гомеостатичних порушень.

Таким чином, хронічна вогнищева одонтогенна інфекція $\epsilon$ не лише поширеною стоматологічною проблемою, але й важливим чинником формування, а також ускладнення та загострення соматичної патології $[18,23]$, що спричиняе високий рівень захворюваності і працевтрат серед населення [23].

Отже, питання впливу хронічного періодонтиту на загальний стан організму людини залишається відкритим. Зміни біохімічних показників при цій патології, особливо в сироватці крові та ротовій рідині, вивчені недостатньо.

Важливим завданням сучасної стоматології, що пов'язана 3 проблемою збереження зуба, $\epsilon$ удосконалення консервативних методів лікування хронічних та загострених форм періодонтиту, що зумовлено деякими нез'ясованими ланками етіопатогенезу цього захворювання та наявністю значної кількості ускладнень $[1,21]$.

Методи лікування періодонтиту поділяються на консервативний, консервативно-хірургічний та хірургічний. Кожен із них має свої переваги i недоліки. Вибір методу лікування залежить від таких критеріїв: клінічного діагнозу; розміру вогнища деструкції кістки; стану тканин пародонта, що оточують зуб; загальносоматичного стану пацієнта; обтяженості алергологічного анамнезу та ін. [4].

На ефективність лікування періодонтиту впливає багато чинників, серед яких: анатомічні особливості будови коренів та розміщення кореневих каналів в окремого індивіда; матеріальнотехнічне забезпечення робочого місця лікарястоматолога; ступінь володіння лікарем методами лікування; бажання пацієнта та зацікавленість лікаря в порятунку хворого зуба; терпіння пацієнта та лікаря, адже інколи консервативне лікування може бути досить тривалим у часі [32].

На думку Gerhard F. Hetz [51], лікування періодонтиту повинно бути проведене швидко, 3 мінімальними затратами, без шкоди для пацієнта, 3 досягненням високоякісного безпосереднього та віддаленого результатів. Кінцевий результат ендодонтичного втручання залежить від успішності і ретельності проведення всіх його етапів [33].

При лікуванні верхівкового періодонтиту лікар ставить перед собою такі задачі: припинення проникнення мікроорганізмів та їх токсинів із системи кореневого каналу в періодонт; ліквідація запалення періапікальних тканин; призупинення дистрофічного процесу; створення умов для відновлення структури та порушеної функції тканин періодонта; стимуляція процесу регенерації; забезпечення повноцінного функціонування зуба; збереження зубного ряду як єдиної і цілісної динамічної системи $[3,5,25,42]$.
Відомо, що для отримання стійкого позитивного результату необхідно досягнути репаративної регенерації тканин перідонта, тому слід обов'язково дотримуватися основних складових елементів ендодонтичного лікування: препарування і формування кореневих каналів; антисептичної обробки системи кореневих каналів; протизапальної та остеорегенеруючої терапії. Отже, успіх лікування деструктивних форм хронічного періодонтиту значною мірою залежить від ефективності препаратів, які проявляють протизапальну дію та стимулюють репаративні процеси в заапікальній зоні [41].

Для антисептичної обробки кореневих каналів запропоновано великий арсенал лікарських засобів, проте ні один із них не відповідає параметрам „ідеального”, оскільки стерильності кореневої системи неможливо досягти ніякими засобами, які були б безпечними для тканин періодонта [20, $25,30,36]$. Як промивні рідини використовуються хлоровмісні препарати, перекис водню, йодинол, нітрофуранові розчини, четвертинні амонієві сполуки, сечовина, перекис сечовини і протеолітичні ферменти. На думку багатьох авторів, у сучасній ендодонтії для оптимальної ірригації каналів слід використовувати розчини гіпохлориду натрію, хлоргексидину біглюконату і етилендіамінтетраоцтову кислоту (ЕДТА) [17, 24, 34, 47, 52].

Провідну роль серед антисептичних препаратів для кореневих каналів при періодонтиті відводять хлоровмісним препаратам i, в першу чергу, гіпохлориду натрію [2, 25]. При цьому вчені вказують на те, що повністю виключити ризик інфікування періодонта при ендодонтичному лікуванні зубів так само неможливо, як і досягти повної стерильності кореневого каналу. У літературі є численні дані про те, що проникнення гіпохлориду натрію за межі апекса під час промивання кореневого каналу призводило до того, що виникали такі небажані явища, як біль, набряк, геморагії, некроз тканин, парестезії. Вiдомі випадки виражених алергічних реакцій на цей препарат аж до анафілактичного шоку [25].

С. Дж. Бонсор та співавт. [1] у своїх дослідженнях виявили, за допомогою лазера, ефективність фотоактивованої дезінфекції кореневих каналів, що включає застосування $20 \%$ розчину лимонної кислоти та 2,25 \% розчину гіпохлориду натрію.

Для медикаментозної обробки кореневих каналів деякі автори пропонують використовувати кілька антисептичних препаратів, наприклад, почергове використання 2,5-3 \% розчину гіпохлориду натрію і $3 \%$ розчину перекису водню або тріаду для ірригації кореневих каналів: натрію гіпохлорид, ЕДТА та фізіологічний розчин [27].

У дослідженнях, проведених М. Heckendorff et M. Hülsmann [50], продемонстровано, що використання як $15 \%$ і $17 \%$ розчинів ЕДТА, так i 2,25\% розчинів гіпохлориду натрію спричиняе цитотоксичні реакції. Аналогічний, не менш виражений, ефект спостерігається і при використан- 
ні $0,1 \%$ розчинів гіпохлориду натрію. При застосуванні розчинів ЕДТА з низькою концентрацією поблизу апекса кореневих каналів у періапікальній ділянці спостерігалося зворотне декальцинування кісткових тканин. Окрім того, застосування ЕДТА може виявляти негативний вплив на процеси нейрогуморальної регуляції, наприклад, за рахунок пригнічення активності макрофагів. Доведено також, що навіть невисокі концентрації розчинів гіпохлориду натрію мають виражену токсичну дію, а $5 \%$ розчин цього антисептика лізує не лише мертві, а й живі тканини [47, 49].

Установлена висока клінічна ефективність катіонних поверхнево-активних речовин при лікуванні запальних захворювань щелепно-лицевої ділянки. Серед них найвищу активність і широкий спектр дії мають такі протимікробні препарати, як мірамістин, хлоргексидин та етоній [45]. Досліджено, що застосування мірамістину при лікуванні періодонтитів пригнічує мікрофлору в кореневих каналах та процеси запалення у випадку гострого і загостреного перебігу патології [37, 39].

Chang Y.C. та співавт. [47] вивчали токсичну дію таких антибактеріальних препаратів, як хлоргексидин, хінозол, метроджил, діоксидин на культури клітин фібробластів ембріона людини і на культури клітин L-41, отриманих із лейкоцитів хворого на лейкемію. У результаті досліджень було виявлено високу антибактеріальну активність і високу токсичність хлоргексидину. Відомо також, що хлоргексидин виявляє токсичну дію на пародонтальні клітини та інгібує синтез білка [49]. Такі антисептики, як гіпохлорид натрію і хлоргексидин пригнічують активність мітохондрій у клітинах тканин пародонта [47].

Деякі автори для лікування періодонтитів ще й тепер місцево використовують антибіотики [46]. При цьому німецьке товариство щелепнолицевої стоматології та німецьке товариство збереження зубів вважають, що у стоматологічній практиці не повинні більше використовуватися такі лікувальні засоби, як похідні фенолу (крезол, формокрезол, парахлорфенол), йодид калію, евгенол, формалін, антибіотики, які досить часто застосовуються лікарями в ендодонтичній практиці, через токсичність, алергенність, швидку втрату лікувальних властивостей у ротовій порожнині. Нетривале їх використання на турундах може бути виправдане лише за наявності ексудату 3 каналу, але й у цьому випадку турунда швидко може стати джерелом інфекції [12].

Постійне і широке та не завжди виправдане використання антибіотиків і синтетичних хіміотерапевтичних засобів може призводити до низки ускладнень, які знижують можливість їх раціонального використання, а саме до виникнення алергічних реакцій i, як наслідок, - до алергізації населення, особливо дітей; розвитку побічної (токсичної) дії на системи і органи людей та медикаментозної резистентності мікроорганізмів до відомих протимікробних засобів; до порушення нормального стану мікрофлори, що призводить до розширення спектра патогенної мікрофлори за рахунок мікроорганізмів, які раніше відносилися до умовно-патогенних, і виникнення нових інфекційних процесів (дисбактеріози, бактеріоносійство, виділення патогенного збудника в навколишнє середовище). Отже, незважаючи на великий вибір антибактеріальних препаратів, пошук нових ефективних методів впливу залишається актуальною задачею ендодонтії [15].

У зв'язку з цим при лікуванні хронічного верхівкового періодонтиту для медикаментозної обробки кореневих каналів необхідно вибирати ліки, які мають біологічну близькість до організму людини, не призводять до вищезгаданих побічних явищ і не спричиняють звикання навіть при тривалому використанні [19]. Такими препаратами є рослинні засоби.

В останнє десятиріччя фітотерапія інтенсивно розвивається, продовжується вивчення властивостей лікарських засобів рослинного походження та науково обгрунтовується доцільність широкого впровадження фітотерапії в клінічну медицину. На сьогоднішній день як антисептики успішно використовуються лікарські рослини, що володіють антибактеріальними, протизапальними, регенераторними, імуномоделюючими й іншими корисними властивостями. Зокрема, для антисептичної обробки кореневих каналів постійних зубів у разі періодонтиту А.В. Борисенко і співавт. [6] застосовували рослинний антибіотик Умкалор, а Е.А. Казанина [16] - фітосуміш зі спирто-гліцеринового розчину череди і листя журавлини.

Як препарат для медикаментозної обробки кореневих каналів постійних зубів, особливо в дітей, добре зарекомендував себе натуральний антисептик вітчизняного виробництва - хлорофіліпт, який виготовляють із листя евкаліпта кулькового, що містить хлорофіли А і В. Цей рослинний препарат має виражену бактерицидну та бактеріостатичну дію до антибіотикозалежних і антибіотикостійких стафілококів. Окрім того, він не пригнічує нормальної мікрофлори організму (кишкову паличку, молочнокислу паличку та ін.). Хлорофіліпт може бути використаний як індикатор чистоти кореневого каналу, оскільки за наявності гнійного ексудату він змінює колір із яскраво-зеленого на сірий. Окрім антибактеріальної активності, він проявляє імуномоделюючу дію, що характеризується підвищенням абсолютного числа Т-лімфоцитів, особливо субпопуляції Тхелперів, і відновленням оптимального співвідношення популяції лімфоцитів. За даними наукових досліджень, використання хлорофіліпту в клініці не супроводжується виробленням стійких до нього штамів стафілокока. Цей лікарський засіб не має алергізуючих, канцерогенних, мутагенних, тератогенних і ембріотоксичних властивостей, тому може успішно використовуватися в практиці дитячого стоматолога $[11,44]$.

Низкою досліджень встановлено, що використання $1 \%$ спиртового розчину хлорофіліпту в 
місцевій терапії хронічного гранулюючого періодонтиту і загострення хронічного гранулюючого періодонтиту скорочує тривалість лікування, зменшує частоту і тяжкість реакції періодонта після пломбування кореневих каналів. Отримані результати безперечно вказують на можливість використання цього рослинного лікарського засобу для лікування верхівкового періодонтиту постійних зубів із незавершеним формуванням тканин кореня та періодонта [11].

Отже, у боротьбі з хвороботворною мікрофлорою кореневих каналів досягти успіху можна за допомогою хіміко-механічного препарування та застосування антисептиків. При цьому основна задача медикаментозної обробки кореневих каналів - максимальне усунення мікрофлори і відновлення кісткової тканини у вогнищі деструкції, тому лікарські засоби, які використовуються при періодонтиті, повинні володіти антибактеріальними властивостями та не справляти негативного токсичного впливу на тканини періодонта.

Для більш повного впливу на навколоверхівкове вогнище запалення необхідна заапікальна терапія [21]. 3 цією метою автори Е.В. Иванова і Г.Н. Чечина [14] пропонують використовувати гідроксіапатит ультрависокої дисперсності 3 антибіотиками. Деякі автори для лікування загострених періодонтитів пропонують застосовувати сорбенти [26], інші вважають за доцільне використання для позаапікальної терапії медикаментозної комбінації, що містить антиоксиданти [38]. Добрі результати дає ендоканальне застосування біоактивного гелю Колапан, що містить у своєму складі клафоран (цефотаксим), лінкоміцину гідрохлорид і метронідазол [29].

Використання ортофен-етонієвої пасти 3 додаванням кісткових ошурків для пломбування кореневих каналів зубів, уражених періодонтитом, після інструментальної та медикаментозної обробки з використанням фурациліну, метрогілу та 2,5 \% розчину ортофену пропонують А.А. Чумаков и соавт. [22]. Автори враховують патогенетичні механізми запалення в періодонті та участь у них простагландинів, оскільки використання нестероїдних протизапальних препаратів блокує накопичення цих медіаторів у вогнищі запалення і запобігає цим подальшій деструкції тканин, що оточують зуб.

Для іригації кореневих каналів із метою поліпшення регенерації кісткової тканини В. Фала и соавт. [43] пропонують використовувати біопрепарат „BioR” (містить значну кількість жирних кислот - гамма-лінолеву і ліноленову, $\beta$-каротин, реаксантин, вітаміни, мікроелементи та інші біологічно активні речовини, необхідні для відновлення і підтримання регенераційних процесів). За спостереженнями авторів, у дослідній групі відновлення кісткової тканини відбувалося у два рази швидше, ніж у контрольній, де для іригації застосовували $3 \%$ розчин гіпохлориду натрію.

Деякими дослідженнями виявлено, що використання гідроксилапатиту для лікування періо- донтитів сприяє стимуляції репаративних процесів у ділянці пульпоперіодонтального сегмента кореня зуба [5, 25, 40].

Науковими працями О.В. Деньги и соавт. [10] доведено, що місцеве лікування періодонтиту за допомогою лікувального комплексу, що містить рифампіцин, фурацилін, преднізолон, димексид (так звана „періодонтальна рідина”) має позитивну дію на метаболізм у кістковій тканині, але не призводить до повного усунення порушень, що виникли, тому як остеотропні препарати автори додатково використовували „Остеомаг” і „Цинктерал”, із яких еx tempore виготовляли пастоподібну суміш на розчині алое.

Вплив верхівкового періодонтиту на загальносоматичний стан організму хворих зумовлює необхідність призначення загального лікування, оскільки терапія цього захворювання повинна бути комплексною і спрямованою не лише на ліквідацію патологічного процесу в тканинах періодонта і відновлення його функції, але і на реабілітацію загального стану, відновлення нормального гомеостазу та стимуляцію захисних сил організму [3, 5, 25]. На важливість комплексного лікування хронічних одонтогенних інфекцій у дітей вказують Н. Foster et J. Fitzgerald [48]. Автори акцентують увагу на ролі педіатрів загального профілю в підтримці розуміння важливості загальносоматичного здоров'я при цій патології.

Для системної терапевтичної корекції стану таких хворих И.А. Горбачева і А.И. Кирсанов [8] пропонують призначати антиоксиданти разом із поліферментативними препаратами, що володіють антиоксидантною, протизапальною, імунокорегувальною, цитопротективною та репараційною діями. На неохідність комплексної терапії із застосуванням препаратів, що підвищують компенсаторно-захисні властивості організму за хронічного періодонтиту, наполягають також А.В. Митронин и соавт. [18].

Із метою запобігання ускладненням місцевого та загального характеру деякі дослідники пропонують людям, хворим на ревматоїдний артрит і періодонтит, обов'язково призначати перорально антибіотики лінкоміцин і рондоміцин [9]. Для загального лікування хронічного гранулюючого періодонтиту в дітей Н.В. Гуревич и соавт. [46] вважають за доцільне призначення антибіотиків цефалоспоринового ряду.

У комплексній терапії хворих із різними формами хронічного верхівкового періодонтиту И.А. Трубка и соавт. [19] пропонують застосовувати антигомотоксичні препарати, а саме, ін'єкції препарату „Траумель C” у перехідну складку проекції верхівки кореня ураженого зуба та дом'язові ін'єкції препарату „Ехінацея композитум” за схемою, а також перорально препарати Са. Для підвищення резистентності організму, прискорення регенерації тканин, підтримання нормального метаболізму і профілактики рецидивів хронічних захворювань у стоматології доцільним $€$ використання вітамінних та полівітамінних 
комплексів ендогенно [13], а для корекції порушень Са-Р обміну - препаратів Са [31].

Отже, медикаментозне лікування хворих на періодонтит, як місцеве, так і загальне, є невід'ємною складовою комплексної терапії цього захворювання.

\section{Література}

1. Альтернативный режим дезинфекции корневых каналов / С.Дж. Бонсор, Р. Ничол, Т.М.С. Рейд [и др.] // Стоматолог. - 2007. - № 8. - С. 34-39.

2. Батюков Н.М. Использование комплекса современных эндодонтических технологий при лечении верхушечного периодонтита / Н.М. Батюков, Н.В. Павлова // Мед. наука молодых ученых: сб. науч. трудов. - Т. 1 (стоматология). - Минск, 2005. - С.7-10.

3. Батюков Н.М. Новые возможности повышения эффективности эндодонтического лечения / Н.М. Батюков, М.А. Чибисова, И.М. Курганова // Институт стоматол. - 2006. - № 2. - С. 58-61.

4. Бир Р. Эндодонтология / Р. Бир, М.А. Бауман, С. Ким. - М.: МЕДпресс-информ, 2004. - 363 с.

5. Борисенко А.В. Методи лікування періодонтитів (огляд літератури) / А.В. Борисенко, Ю.Ю. Кодлубовський // Современная стоматол. -2010 . - № 1. - С. 15-20.

6. Борисенко А.В. Порівняльне вивчення протимікробної дії умкалору на мікрофлору кореневих каналів зубів / А.В. Борисенко, О.Ф. Несін, Л.З. Гаврилова // Современная стоматол. - 2009. - № 2. - С. 17-20.

7. Влияние сочетанных поражений осложненного кариеса и воспалительных заболеваний пародонта на состояние зубочелюстной системы / Л.Ю. Орехова, Т.В. Кудрявцева, В.А. Осипова [и др.] // Пародонтология. - 2004. - № 2 (31). - С. 8-14.

8. Горбачева И.А. Хроническая одонтогенная очаговая инфекция и соматические заболевания / И.А. Горбачева, А.И. Кирсанов // Пародонтология. - 2001. - № 4 (22). - C. 35-39

9. Гринин В.М. Эффективность применения антибиотикотерапии в лечении хронического деструктивного верхушечного периодонтита на фоне системного остеопороза у больных ревматоидным артритом / В.М. Гринин, В.В. Деркач // Стоматол. для всех. 2010. - № 2. - C. 4-8.

10. Деньга О.В. Результаты биохимического исследования эксудата, полученного из корневых каналов постоянных зубов с несформированными корнями при лечении периодонтита у детей / О.В. Деньга, Л.Б. Цевух, Н.Ф. Коновалов // Вісн. стоматол. 2009. - № 1. - С. 15.

11. Елизарова В.Е. Хлорофиллипт как эффективный антисептик при лечении периодонтитов / В.Е. Елизарова, Е.А. Савинова, В.Ф. Щеголева // Стоматол. дет. возраста и профилактика. - 2003. - № 1-2. - С. 17-18.

12. Заверная А.М. Применение гидроксида кальция при лечении деструктивных форм хронического периодонтита / А.М. Заверная, Т.Н. Волосовец, Н.Н. Юнакова // Дентал. технол. - 2004. - № 6 (19). - С. 29-33.

13. Зорян Е.В. К выбору витаминных препаратов в стоматологии / Е.В. Зорян // Стоматолог. - 2003. - № 12. C. 6-9.

14. Иванова Е.В. Сравнительная оценка биологических свойств гидроксиапатита ультравысокой дисперсности Остим-100 / Е.В. Иванова, Г.Н. Чечина // Клин. стоматол. -2000 . - № 2. - С. 36-37.

15. Ішков М.О. Характер мікрофлори кореневих каналів при хронічних верхівкових періодонтитах та іï порівняльна чутливість до дії антимікробних препаратів in vitro / М.О. Ішков, О.Б. Бєліков, І.П. Бурденюк // Бук. мед. вісник. - 2012. - Т. 16, № 2 (62). - С. 67-69.

16. Казанина Е.А. Эффективность лечения деструктивных форм хронического верхушечного периодонтита фи- топастой / Е.А. Казанина // Современные методы диагностики, лечения и профилактики стоматологических заболеваний: сб. науч. трудов. - Рязань, 2005. C. 74-78.

17. Кантаторе Джузеппе. Ирригация корневых каналов и ее роль в очистке и стерилизации системы корневых каналов / Джузеппе Кантаторе // ДентАрт. - 2004. № 3. - С. 62-69.

18. Клинико-иммунологическая характеристика деструктивных форм хронического периодонтита / А.В. Митронин, Т.Г. Робустова, Ю.М. Максимовский [и др.] // Рос. стоматол. ж. -2005 . - № 1. - С. 29-34.

19. Клинические аспекты применения антигомотоксических препаратов в комплексном лечении хронического периодонтита / И.А. Трубка, И.А. Моложанов, С.А. Хитрова [и др.] // Укр. стоматол. альманах. 2007. - № 5. - С. - 31-33.

20. Коваль А. Дезинфекция корневых каналов. А так ли все просто? / А. Коваль // Современная стоматол. 2006. - № 4. - C. 39-40.

21. Котелевська Н.В. Обгрунтування методу заапікальної терапії гострого гнійного та загостреного хронічного верхівкового періодонтитів / Н.В. Котелевська // Вісн. стоматол. - 2004. - № 4. - С. 30-33.

22. Лечение хронического периодонтита с использованием ортофена в эксперименте / А.А. Чумаков, С.П. Бойкова, Е.Н. Борисова [и др.] // Стоматология. 1995. - № 4. - С. 8-10.

23. Лукиных Л.М. Верхушечный периодонтит / Л.М. Лукиных, Ю.Н. Лившиц. - Нижний Новгород: Издательство НГМА, 2004. - 86 с.

24. Любченко О.В. Использование материалов компании LaTus в практической эндодонтии / O.В. Любченко // Стоматолог. - 2011. - № 7-8. - С. 4-6.

25. Макєєв В.Ф. Порівняльна експериментальна оцінка репаративного остеогенезу кісткових дефектів щелеп, заповнених різними остеопластичними біоматеріалами / В.Ф. Макєєв, О.М. Сірий, М.О. Черпак [та ін.] // Нов. стоматол. -2010 . - № 1. - С. 42-45.

26. Максимовский Ю.М. Основные направления профилактики и лечения хронического воспаления в области периодонта / Ю.М. Максимовский, А.В. Митронин // Рос. стоматол. ж. - 2004. - № 1. - С. 16-18.

27. Микробиологическая оценка эффективности медикаментозной обработки корневых каналов при периодонтите / Т.Л. Рединова, Н.А. Прилукова, Л.А. Чередникова [и др.] // Институт стоматол. - 2010. - № 2. C. $58-59$.

28. Митронин А.В. Изучение влияния хронического апикального периодонтита на состояние организма пациента / А.В. Митронин, И.Д. Понякина // Стоматология. - 2007. - № 6. - С. 26-29.

29. Митронин А.В. Принципы, методы и средства лечения хронического периодонтита при комплексной реабилитации пациентов / А.В. Митронин // Стоматология. -2005 . - № 6. - С. 6-9.

30. Ніколішин А.К. Сучасні методи медикаментозної обробки кореневих каналів при хронічних верхівкових періодонтитах / А.К. Ніколішин, Ю.В. Сідаш // Укр. стоматол. альманах. - 2010. - № 3. - С. 36-39.

31. Петрушанко Т. Применение препаратов кальция в стоматологии / Т. Петрушанко // Дент Арт. - 2008. № 1. - C. 23-32.

32. Пожарицкая М.М. Использование информационноволновой терапии в лечении деструктивных форм хронического верхушечного периодонтита / М.М. Пожарицкая, В.А. Путь, И.В. Соколов // Рос. стоматол. ж. - 2004. - № 2. - С. 19-21.

33. Політун А.М. Фізіотерапевтичні методи в комплексному лікуванні ускладнень ендодонтичних втручань / А.М. Політун, О.А. Значкова, О.Д. Головчанська // Нов. стоматол. - 2011. - № 3. - С. 14-18. 
34. Рабинович И.М. Совершенствование эндодонтического лечения заболеваний пульпы и периодонта / И.М. Рабинович, И.Т. Цаболова // Клин. стоматол. 2011. - № 2. - С. 72-74.

35. Роль микрофлоры полости рта в развитии инфекционного эндокардита / В.Н. Царев, М.А. Саркисян, С.Н. Крутова [и др.] / Стоматол. для всех. - 2009. № 2. - С. 18-20.

36. Романенко И.Г. Клинические аспекты современных средств и методов медикаментозной обработки корневых каналов / И.Г. Романенко, С.М. Горобец, М.А. Смирнов // Стоматолог. - 2011. - № 7-8. C. $8-15$.

37. Симоненко Р.В. Изучение адгезивных свойств мирамистиновой пасты в корневых каналах зубов / Р.В. Симоненко // Современная стоматол. - 2004. № 3. - C. 30-32.

38. Синиця В.В. Застосування антиоксидантів у комплексному лікуванні хронічних верхівкових періодонтитів: автореф. дис. на здобуття наук. ст. канд. мед. наук: 14.00.22 / В.В. Синиця. - Львів, 2003. - 20 с.

39. Сірий О.М. Експериментальне порівняльне дослідження остеоінтегративних властивостей біополімерного резорбуючого композиту на основі полілактиду і кальцій-фосфатних синтетичних біоматеріалів / О.М. Сірий, М.М. Угрин, М.О. Черпак // Нов. стоматол. 2010. - № 3. - С. 47-52.

40. Скотаренко А.В. Использование гидроксиапатита ультравысокой дисперсности «Остим-100» и циклофосфана при лечении деструктивных форм хронического периодонтита / А.В. Скотаренко // Современная стоматол. - 2002. - № 3. - С. 25-30.

41. Таиров В.В. Эффективность комбинированной терапии деструктивних форм периодонтита (экспериментально-клиническое исследование): автореф. дис. на соиск. уч. степ. канд. мед. наук. - Краснодар, 2010. $20 \mathrm{c}$.

42. Токмакова С.И. Клиническая эффективность применения препаратов гидроокиси кальция для лечения деструктивных форм хронического периодонтита / С.И. Токмакова, Е.С. Жукова // Институт стоматол. 2008. - № 4. - С. 46-47.

43. Фала Валериу. Комплексное рациональное лечение хронических деструктивних верхушечных периодон- титов / Валериу Фала, Валериу Бурлаку // Dent Art. 2012. - № 1. - C. 20-28.

44. Хоменко Л.А. Врачебные вмешательства в корневых каналах временных зубов. Часть 2: как лечить? Л.А. Хоменко, Н.В. Биденко, А.И. Зеленкова // Современная стоматол. - 2008. - № 3. - С. 66-73.

45. Чумакова Ю.Г. Сравнительная оценка антимикробного действия препаратов на основе хлоргексидина и экстрактов лекарственных растений на микрофлору пародонтальных карманов / Ю.Г. Чумакова, А.В. Осторовский, А.А. Вишневская // Стоматолог. 2011. - № 10. - C. 49-52.

46. Эффективность применения антибиотиков цефалоспоринового ряда у детей с хроническими периодонтитами / Н.В. Гуревич, В.П. Болонкин, А.М. Хамадеева [и др.] // Актуал. пробл. современ. науки: труды 4-й Международной конференции молодых ученых и студентов. - Самара, 2003.- С. 39-41.

47. Chang Y.C. The effect of sodium hypochlorite and chlorhexidine on cultured human periodontal ligament cells / Y.C. Chang, F.M. Huang, M.Y. Chou // Oral. Med., Oral Pathol., Oral Radiol., Endod. - 2001. - Vol. 92 (4). P. 446-50.

48. Foster H. Dental disease in children with chronic illness / H. Foster, J. Fitzgerald // Arch Dis Child. - 2005. Vol. 90 (7). - C. 703-8.

49. Hauman С.Н.J. Биосовместимость стоматологических материалов, используемых в современном эндодонтическом лечении: обзор. Часть 1. Внутриканальные лекарства и вещества / C.H.J. Hauman, R.M. Love // Эндодонтия today. - 2003. - Т. 3, № 1-2. - C. 78-88.

50. Heckendorff М. Принцип действия и показания к применению хелатосодержащих препаратов в эндодонтии / M. Heckendorff, M. Hülsmann // Новое в стоматол. -2003 . - № 5. - С. 38-41.

51. Hetz Gerhard F. Endodontie. Theorie oder Praxis? / Gerhard F. Hetz // Новое в стоматол. - 2002. - № 7. C. 19-20.

52. Siqueira José F. Community as the unit of pathogenicity: An emerging concept as to the microbial pathogenesis of apical periodontitis / José F. Siqueira, Isabela N. Rôças // Oral Surg., Oral Med., Oral Pathol., Oral Radiol., Endod. - 2009. - Vol. 107. - P. 870-878.

\section{ВЛИЯНИЕ ПАТОЛОГИИ ПЕРИОДОНТА НА ОБЩЕЕ СОСТОЯНИЕ ОРГАНИЗМА. СОВРЕМЕННЫЕ МЕТОДЫ МЕДИКАМЕНТОЗНОГО ЛЕЧЕНИЯ ПЕРИОДОНТИТА ПОСТОЯННЫХ ЗУБОВ: ПРЕИМУЩЕСТВА И НЕДОСТАТКИ (ОБЗОР ЛИТЕРАТУРЫ)}

\section{И.Р. Костюк}

Резюме. В статье проанализированы литературные данные по проблеме влияния хронической одонтогенной очаговой инфекции на общее состояние организма человека. Проведен анализ существующих методов местного и общего лечения патологии периодонта, отражены их преимущества и недостатки. Обоснована необходимость комплексного лечения хронического и обостренного хронического периодонтита постоянных зубов. Указано на целесообразность использования растительных средств в терапии периодонтита.

Ключевые слова: общее состояние организма, периодонтит постоянных зубов, медикаментозное лечение.

\section{INFLUENCE OF PERIODONTAL DISORDERS ON GENERAL WELL BEING OF THE BODY. THE MODERN METHODS OF PHARMACOLOGICAL TREATMENT OF APICAL PERIODONTITIS IN PERMANENT TEETH, ADVANTAGES AND DISADVANTAGES (REVIEW OF THE REFERENCES)}

\section{I.R. Kostiuk}

Abstract. The article demonstrates the analysis of the data regarding the affect of odontogenic local infection caused by apical periodontitis on the general well being of the body. We have investigated the current local and general management of periodontal disorders with indication of their advantages and disadvantages. We also explain the need of complex 
treatment of acute apical chronic periodontitis and its exacerbation in permanent teeth in children and the requirements in herbal pharmacological agents in treatment of periodontal disorders.

Key words: general wellbeing of the body, apical periodontitis in permanent teeth, pharmacological treatment.

SHEE «National Medical University» (Ivano-Frankivsk)

Рецензент - доц. Н.Б. Кузняк

Buk. Med. Herald. - 2014. - Vol. 18, № 3 (71). - P. 199-205

Надійшла до редакції 23.04.2014 року

(C) I.P. Костюк, 2014

УДК 612.813:612.884

О.Я. Мокрик, В.М. Горицький

\section{СУЧАСНІ МЕТОДИ ФУНКЦІОНАЛЬНОЇ ДІАГНОСТИКИ ХІРУРГІЧНОГО СТРЕСУ (ОГЛЯД ЛІТЕРАТУРИ ТА ВЛАСНІ ДАНІ)}

Львівський національний медичний університет імені Данила Галицького

Резюме. В огляді подано нові дані про функціональні методи діагностики, які застосовуються для виявлення фізіологічних проявів гострого стресу в осіб під час проведення хірургічних та стоматологічних втручань. Розглянуто сучасні науково-технічні розробки, впроваджені в медичну практику, які дозволяють об'єктивно оцінити психоемоційний стан хворих, реактивність їх нервової, серцево-судинної, дихальної систем

Вступ. Як відомо, хірургічні втручання супроводжуються гострими стресовими реакціями у хворих, які мають стадійний характер і зумовлюють функціональні зміни з боку нервової, серцево-судинної, дихальної, ендокринної та імунної систем [3, 4, 26, 35, 41]. Серед факторів, що їх формують, виділяють: психоемоційне напруження (тривожність, страх, боязнь), пошкодження тканин під час операції, післяопераційний больовий синдром та інші $[4,28,32,34,35]$. Вираженість стресових проявів залежить від загального стану організму пацієнтів, адекватності їх премедикаційної підготовки, ефективності анестезіологічного захисту в інтраопераційний період, тривалості і травматичності самого оперативного втручання $[2,24,25,35]$. Надмірний альтеруючий вплив хірургічного стресу призводить до напруженості захисних сил організму, інтенсифікації метаболічних процесів, порушень гемодинаміки та інших несприятливих змін, що стають причиною погіршення якості життя пацієнтів [20, 43]. Тому розробці ефективних методів діагностики гострого стресу в пацієнтів хірургічного профілю надається великого значення. Функціональна діагностика - це одна 3 найбільш активно розвиваючих галузей у сучасній медицині. Причиною тому служить бурхливий процес впровадження новітніх розробок і комп'ютерних технологій. За останне десятиліття в цьому напрямку досягнуто значний прогрес, отримано нові результати клінічних досліджень, які знайшли відображення у вітчизняних та закордонних фахових виданнях. на тлі стресогенного впливу хірургічної травми, а також промоніторити ефективність премедикаційної підготовки та застосованих методів анальгезії. Представлено результати власних досліджень.

Ключові слова: функціональні методи діагностики, хірургічний стрес, психоемоційний стан, больова чутливість, вегетативна нервова система, серцевосудинна система, дихальна функція, секреція слини.

Мета дослідження. Провести аналіз джерел літератури, в яких висвітлено питання розробки та клінічного застосування сучасних функціональних методів діагностики гострого стресу в пацієнтів хірургічного та стоматологічного профілів, представити результати власних досліджень.

3 метою визначення рівня психоемоційного напруження у пацієнтів напередодні хірургічного втручання, для виявлення в них стресових проявів й обгрунтування необхідності застосування премедикацій активно використовується сенсометричний метод, який дозволяє на основі оцінки сенсорних порогів визначати рівень емоційного напруження, автоматично визначати до якої групи ризику належить обстежуваний пацієнт [11, $12,27]$. Сенсометрія, як суб'єктивно - об'єктивний метод, дозволяе отримати результати за умови свідомої участі пацієнта в оцінці власних відчуттів. Досліджено, що існує обернена залежність між рівнем тривожності і показниками сенсорних порогів пацієнтів [12, 18, 27]. Встановлено, що психоемоційний стрес може впливати на ступінь больової чутливості. В одних випадках вона знижується - у хворих розвивається стрес - індукована анальгезія, в інших - відбувається загострення больового відчуття [18]. Для вивчення захисних (рухових) реакцій людини у відповідь на дію больового стресора використовують методики електроміографії. Найпоширенішою стала методика оцінки ноцицептивного флексорного рефлексу (НФР) - згинання гомілки при електричній стимуляціï n. suralis. НФР дозволяє об'єктив- 